\title{
Leaving Theravāda Buddhism in Myanmar
}

\author{
Niklas Foxeus
}

\section{1 \\ Introduction}

This chapter examines narratives of Burmese Buddhists who have left the "traditional" Theravāda Buddhism in Burma, into which they were born, for the teachings - stamped "heretical" and illegal by the state - of a dissident Buddhist monk, Ashin Nyāna.

Since 1980, the State and monastic authorities have sought to regulate orthodox Theravāda Buddhism by means of the law. Monastic courts backed by the state have scrutinised cases charged with "heresy" (P. adhamma), ${ }^{1}$ that is, teachings not considered to be in accordance with the Buddhist canon, a contested issue. Heresies are declared illegal and the dissemination of such teachings is punishable with imprisonment (see Tin Maung Maung Than 1993; Janaka Ashin and Crosby 2017). Apostasy and heresy tend to blend into one another, and the state may serve as an arbiter to decide the nature of the case (see Larsson 2018: 7, 20). From the state's point of view, Ashin Nyāna and his followers represent a kind of disloyal Theravāda Buddhist apostates disseminating doctrines that deviate from orthodox Theravāda Buddhism and that pose a threat to the maintenance of the latter in society. From the perspective of Ashin Nyāna and his followers, Theravāda Buddhism represents a deviation from the original teaching of the Buddha, and they have therefore abandoned it and do no longer attribute authority to its monks. They do not regard their teaching as a branch of Theravāda Buddhism and therefore it cannot, in their view, be regarded as a "heresy."

The state-sanctioned form of Buddhism represents a collectivist and antisecularising tendency, and likewise an enchanted form of religion, with a "traditional" cosmology comprising 31 levels, with heaven and hell, inhabited by gods, hell-beings, ghosts, and spirits.

1 In this chapter, "P." is an abbreviation for Pāli. All foreign words are Burmese, unless otherwise indicated. The word "karma" is used instead of kamma, since the former has been adopted into English.

2 They tend to view Theravāda on a par with Mahāyāna Buddhism, both of which they regard as later corruptions of the pristine teaching of the Buddha. 
Many of the "heresies" represent novel reinterpretations of Buddhism that have emerged in interplay with modernisation, Western science, and "Orientalist" views on "original" Buddhism. The development of doctrinal lay Buddhism began in the colonial period and continued in the post-independence period, with Buddhist monks disseminating intellectualised forms of Buddhism to the laypeople, especially simplified versions of insight meditation (P. vipassanā), teachings that had previously been reserved for the monks (Braun 2013; Hout$\operatorname{man} 1990){ }^{3}$

Ashin Nyāna (1938-) was ordained a Buddhist monk but was defrocked in 1983, whereupon he set up his own group called mou-pyā-wāda, "The Doctrine of the Sky-Blue [One]." At that time, he began wearing blue robes consisting of a shirt and baggy pants. His adherents still regard him as a monk exercising corresponding authority. Thereby he not only left the monastic community (P. sańgha) but also Theravāda Buddhism. Ashin Nyāna claimed to have rediscovered the original teaching of the Buddha that preceded the emergence of the allegedly corrupt Theravāda Buddhism. He has served three prison sentences for having disseminated a "heretical" form of Buddhism. Last time was in 2010 and he was released in January 2016. Today, this is an underground, illegal new religious movement.

Ashin Nyāna's teaching represents a secular form of Buddhism, acknowledging only one life; and rejecting the rebirth, Buddhist cosmology, and the metaphysical underpinnings of the teaching of karma. Moreover, it constitutes an intellectualised form of Buddhism informed by Western rationality and science. It is characterised by an individualist this-worldly orientation, and psychologisation, anti-ritualism, and scripturalism, with an emphasis on doctrines and ethics. In contrast to traditional Buddhism, it focuses on The Four Noble Truths and The Eightfold Path. His teaching is also known as pyissouppān-kamma-wāda, the "doctrine on present karma." Rejecting the existence of spirits, gods and other supernatural beings, he explained them as "mind-creations" (seitta-zāa). The cosmological levels of the Buddhist cosmology were, according to him, mere symbols for mental states. Most importantly, he reinterpreted Buddhist doctrines and simplified them so that they could serve as a practical technology for resolving everyday problems for the Buddhist laypeople, including marriage and business problems. In this teaching, most of the traditional Theravāda Buddhist practices and rituals for the laypeople are abandoned, including meditation, merit-making rituals, giving alms to monks, and presenting offerings to Buddha statues.

3 For a broader depiction of Burmese Buddhism and its history, see Foxeus 2016. 
Based on fieldwork in Myanmar, the aim of this chapter is to - using various theoretical and analytical frameworks - investigate interlinked deconversion and conversion narratives of my informants divided into three different groups, based on their attitudes (secular, devotional or spiritual seekers) and the kind of Buddhist practice in which they were mainly engaged before converting.

\section{Previous Research and Empirical Material}

As for previous research on deconversion and conversion in Myanmar, it has mostly been concerned with cases between Buddhism, Christianity and Islam (Tint Lwin 1997; Charney 2006; Ikeya 2012). To my knowledge, there are not yet any case studies in any of these fields.

The words "apostasy" and "defection" may carry negative connotations, implying a blaming the individual for break of loyalty (Streib et al. 2009: 17). The term "deconversion," which refers to a disaffiliation process, expresses, Streib et al argue $(2009,17)$, less prejudice and it suggests that deconversion is as legitimate as conversion. Earlier scholarship on conversion was shaped by Protestant subjectivist notions of conversion as sudden and privileged interior states. Today it is mainly understood as a gradual process taking place over an extended time, and the subjective orientation is expanded by including other themes, factors and contexts (see Rambo and Farhadian 2014; Streib et al. 2009, chap. 1). According to J.D. Barbour, the rise of deconversion has grown out of increasing individualism and religious pluralism in modernity (cited in Streib et al. 2009: 21). Although these changes have mainly been examined with regard to the West, that situation is, to some degree, comparable to Burma and other countries in Southeast Asia since the post-war period.

In 2014-2017, I conducted about 65 semi-structured interviews with Ashin Nyāna's followers, mainly in Upper Burma but also in Lower Burma. Since Ashin Nyāna was arrested in 2010 and his teaching was declared to be "heretical" in 2011, the movement is formally illegal and has gone underground. Today, followers tend to keep their views to themselves and avoid discussing them in public. The movement consists of several informal social networks, many of which are unrelated to one another.

\section{$3 \quad$ New Findings Focusing on "Leaving Religion"}

Among Ashin Nyāna's followers are found urban laypeople such as academics, teachers and other intellectuals; business people, some ex-communists, 
student activists, military officers and politicians, but also some peasants and poor people from the lower middle-classes. The majority are men. Most of them had practiced "traditional" Burmese Theravāda Buddhism before they converted to Ashin Nyāna's brand of Buddhism. They view his teaching as the "true" teaching of the Buddha.

The majority of my informants had undergone socialisation, in which Theravāda Buddhist notions and values, including its cosmology, became an integral part of their habitus and general taken for granted assumptions. One man had to attend Ashin Nyāna's courses three times because he was so perplexed by this teaching. Most of my informants described a gradual deconversion process that developed over several years. Since Ashin Nyāna's teaching represents an intellectualised form of Buddhism, many of them described cognitive discrepancy such as intellectual doubt (see Paloutzian 2005: 336-338) as reason for leaving Theravāda Buddhism. They read books or listened to sermons delivered by Ashin Nyāna, and doubts began to grow in some of them, and others were already in doubt.

This motif was sometimes combined with an explicit or implicit moral criticism of the monastic community. Some expressed resentment towards the monks for having deceived them; one referred to them as "rubbish" (ahmaik); a former student activist even said that Theravāda Buddhism had "enslaved them" (kyun-pyu). Such critique resembled ideology criticism viewing Theravāda Buddhism as representing a kind of Marxian "false consciousness" (compare Snow Machalek 1983: 267) sustained by the monks. In contrast to most Theravāda Buddhists, many followers do not give alms-food to the monks but instead give food to poor and needy people. In other cases, the intellectual doubt and moral criticism was combined with emotional suffering. Many said that Theravāda Buddhism brings about "expectations" (ahmyaw), for instance, for a better next rebirth, and "fear" (akyauk), for instance, to be reborn in hell. Due to one or several of these circumstances, they decided to leave Theravāda Buddhism.

These reasons for leaving Theravāda Buddhism correspond to several of the motives for deconversion in the scholarly literature, for instance, intellectual doubt, denial or disagreement with specific beliefs; moral criticism, and emotional suffering (Streib et al. (2009, 21-22). In a general sense, a "key element to any conversion or transformation process must be some element of doubt, pressure, or motivation to change" (Paloutzian 2005:336). However, the deconversion or disaffiliation literature (Streib et al. 2009; Bromley 1998) does not seem to emphasise one aspect that was important in my material. The majority of my informants would not have left their religion if they had not have found a viable alternative. In their narratives, the deconversion process was intimately 
intertwined with the conversion process. For that reason, the one cannot be separated from the other. This chapter is thus about leaving one religion for another.

In Burma, there is a rhetorical dichotomy between Buddhists who practice in a passive and in an active mode, respectively, and that has informed many of my informants. In the early post-independence period in Burma, many Buddhists discarded what is sometimes rather pejoratively called mi-you-hpalā-bouddha-bhäthā, a simple, ritualistic form of Buddhism inherited from their parents focused on merit-making. It is implied that it represents a passive mode, and that it is performed mechanically and without knowledge. ${ }^{4}$ Instead, they set out to find the "true" or "authentic" Buddhism that required commitment, knowledge, and intense practice (see Houtman 1990). For many Burmese at that time, it meant practicing a form of insight meditation that was marketed mainly by many monks (see Houtman 1990). Others became adherents of dissident monks, including Ashin Nyāna.

This dichotomy is reminiscent of the distinction between the active and the passive convert in the West, with those affiliated with new religious movements representing an "active, meaning-making subject" (Streib et al. 2009: 19-20). This is an individualistic trend in Burma emphasising agency and the converts as active subjects (see also Staples and Mauss 1987; Streib et al. 2009; Rambo and Farhadian 2014: 8). My informants can be divided into three groups depending on their preconversion practice: 1) those with a more secular orientation; 2) those practicing devotional Theravāda Buddhism; and 3) those having embarked on a spiritual quest to discover "true" Buddhism. All my informants represented the active mode, looking for alternatives to the passive mode of religiosity, but for different reasons. Before conversion, they all (in the present sample) self-identified as Theravāda Buddhists. In the following, I will give some examples from these three groups.

The first group comprises people who had already acquired a secular world view, such as communists and other sceptics. After the communist movements died out in Burma by the end of the 1980s, some communists felt disoriented and sought to restore their former Buddhist identity. Others, including farmers, also had a secular world view, but still identified as Buddhists and seemed to look for an alternative interpretation of Buddhism that was more congruent with their worldview.

4 This kind of Buddhist practice is sometimes called "karma Buddhism" because it is a ritualistic, devotional form of Buddhist practice that is oriented towards improving one's karma by performing merit-making activities, thereby hoping to achieve a better rebirth in the next life (see Spiro 1982; he uses the label "kammatic Buddhism"). 
One man was 68 years old, a former communist leader, political activist and military officer. Today he is retired and runs a tea shop. "When I was 14 years old, I became a communist [-], a "non-religious person" (bhäthā-me-th $\bar{u}$ ), and I abandoned Theravāda Buddhism." This remained until 1988, at which time he relinquished communist ideology, but he still retains communist sympathies. While he was a military officer, he led military units in wars in the border regions ${ }^{5}$ and witnessed hundreds of people die. After he left the army in 1988, he felt traumatised by the wars and began drinking alcohol. He now returned to Theravāda Buddhism for solace and started to practice insight meditation. At this time, he also began believing in previous and future existences, and the cosmology. But, it seems, he was not entirely convinced. Doubts gnawed in the back of his mind.

In 2005, he heard about Ashin Nyāna for the first time, and he met him twice that year. During this period, he read a book written by him about "desire" (P. $\tanh \bar{a})$ and began to doubt the Theravāda Buddhist doctrine on that matter. According to the latter, he explained, all desire, even sexual desire for one's wife and desire for good food, is tanhā and must be quenched. He did not find this convincing anymore. Ashin Nyāna taught that tanh $\bar{a}$ merely refers to wrongful desire, not desire as such. He became convinced that this constituted the Buddha's true teaching. He also doubted the Theravāda teaching on previous and future existences and the teaching on karma, and now he realised that these were not taught by the Buddha. For this reason, he has stopped giving alms to the monks, and has even tried to persuade others from doing so. Moreover, in his view, communism is partly compatible with Ashin Nyāna's teaching. He left Theravāda Buddhism the same year and became a follower of Ashin Nyāna.

The second group consists of people who converted to Ashin Nyāna's teaching from devotional forms of Theravāda Buddhism. One woman was 47 years old who runs a shop. Before she converted, she had problems with everything in her life - her marriage and business. Her siblings were wealthy, but she was poor. Her parents and the monks had explained that her misery was caused by bad karma from previous existences. The monks discouraged her from making effort to gain success in her business, and from cultivating greed (P. lobha) because the latter would bring about bad karma. But, as a businesswoman, she explained, she does have some greed as she wants to make profit. Success, the monks explained, would come by itself. If she donated to the monks, she would acquire karmic merit and a better rebirth. However, she did not want to donate large sums of money. Because of her present misery, she thought she

5 This combination of loyalties was quite dangerous because the Burmese army fought against the communists at the time. 
would be reborn in hell. She gave up her hope in improving her situation by her own effort. Due to her bad karma, she turned to Buddhist spirits with offerings, wishing for success in business, which however, was still not forthcoming.

Through some neighbours she learned about Ashin Nyāna in 2009, and read a couple of books during one year. Thereby, she came to realise that the Theravāda teachings were wrong - the teaching on previous and future existences, the teaching about karma, the cosmology, and so forth. Later Ashin Nyāna told her that she should make effort to be successful in business and cultivate "right greed." Today she is a devout follower and has, she claimed, become a successful businesswoman. She gives far less donations nowadays. Instead she uses her profit for her family and business.

Another woman was 47 years old, runs her own business and became a follower of Ashin Nyāna in 2006, but she had heard about him already in 1982. Her business, she explained, is successful and she has become wealthy thanks to his teaching. As a Theravāda Buddhist, she had donated large sums of money to the monks. She gave more than she had and became poor. She also spent much money in vain on offerings to Buddhist spirits, saying, "Until 2006 I followed the traditional Theravāda Buddhism. My life wasn't successful. Why not? [-] Due to bad karma in my previous life I wasn't successful in my present life. That is what I believed."

The monks had explained her poverty by her bad karma from previous existences, and the only way to improve her future condition was to give alms to the monks. Through Ashin Nyāna's teaching she realised that her poverty was caused by her actions in this present life. She became interested in his explanation of the Eightfold Path. Previously, she had often attended sermons delivered by Theravāda monks who recited texts in Pāli that the audience could not understand, and they were not encouraged to practice that path. "But," she said, "one must practice to have real experiences." By contrast, Ashin Nyāna preached in Burmese and he emphasised the application of Buddhist teaching in their everyday lives. After having left Theravāda Buddhism, she felt liberated: "Without having to restrain myself and holding back anymore, I nowadays feel free and have found peace of mind." Theravāda Buddhism had, in her experience, made her passive. Only after she became a follower of Ashin Nyāna, she became an active agent that could raise herself from poverty:

My business also became successful because I managed to work in a sound way. In the past, when I followed the teaching of the traditional Theravāda Buddhist monks, my business was not successful, and I became disappointed. They said that it was because of my bad karma from 
previous existences. I wasted time and I was passive. Nowadays I always make effort [to improve my situation] because I have come to know Ashin Nyāna's teaching saying that one should make effort and be active. I'm always active and in a good mood.

Both these women sometimes give donations, mostly to poor and needy people, including some monks, but without expecting anything in return, such as a better rebirth, since they have discarded such beliefs.

The third group consists of spiritual seekers looking for an alternative to traditional Theravāda Buddhism, but without leaving the latter before finding the "true" teaching of the Buddha. One man was 41 years old and runs a workshop for electronics. In his youth, he was ordained a Buddhist novice and later a monk for a short period of time. Since then, he has been interested in religious matters, and has practiced Theravāda Buddhist insight meditation. Before he found Ashin Nyāna's teaching, he had also paid interest in the doctrines of other dissident monks. Being an avid reader of books about Buddhism, he was looking for answers, for instance, to questions regarding previous and future lives. He nourished some doubts.

In 2002, a follower of Ashin Nyāna left a cassette player at his workshop. When he was going to repair it, he found a cassette in it with a sermon of Ashin Nyāna about what will happen after death. Later the follower gave him books written by Ashin Nyāna. He came every day, and they went to tea shops discussing Buddhism until dawn. In 2004 he met Ashin Nyāna for the first time and listened to his sermons, but he did not immediately become a follower. Now he learned from him that the Buddha never taught about previous and future existences. Such questions were part of the ten questions that he left unanswered. The Theravāda monks in Burma, the adherent said, never speak about these unanswered questions. He came to realise that the teaching of rebirth is derived from Hinduism and was not preached by the Buddha; and that Theravāda Buddhism represents a false teaching, "The Buddhist teaching I know now is quite different from that. [Formerly,] I performed a variety of [Theravāda] Buddhist practices. But now I don't perform them anymore. None of them are concerned with the Buddha's teaching. Now I know that I must avoid them." Around six months after his first meeting with the monk, he became a devout follower.

Another man was 65 years old, runs a business, is a politician and became a follower in 2000. He was critical to the traditional Burmese Theravāda Buddhists who, he explained, tend to follow the instructions of the monks without knowing why and how they should practice, and without asking critical 
questions. ${ }^{6}$ As a Buddhist, he wanted to learn more about doctrines and practices by reading and studying books about Buddhism, and listening to sermons delivered by Theravāda monks. He learned from them that whatever he does is dukkha, "suffering," and that human existence is inherently suffering. He practiced insight mediation and breathing exercises (P. ānāpāna) at various insight meditation centres for three years. Although he sat cross-legged meditating for several hours a day, through which he achieved a temporary inner peace, as soon as he began working with his business, the spiritual joy (P. sukha) disappeared. A sense of disappointment aroused in him regarding Theravāda meditation.

In this period, around 1999, he heard about Ashin Nyāna and his opposite view that "the human existence is the noblest one." He found this idea strange. Later he met an adherent of him who explained that his problem of the temporary inner peace, followed by worries and tensions (P. soka), was caused by the fact that he accepted it. Initially, he became sceptic but borrowed a DVD with a sermon delivered by Ashin Nyāna where he explained the technique of being "mindful of the causes" to mental tensions. By that means, one should search for these causes in present actions (karma), not in a previous life. Suffering, he now realised, is not inherent in the human existence as such, which the Theravāda monks had taught him, but is caused by one's actions in the here and now in one's present life. In this way, he managed to achieve lasting inner peace, not in a cross-legged position but in all everyday activities. At the same time, he became critical to the Theravāda Buddhist doctrine on karma and exemplified with farmers who wrongly believe that their misery is caused by karma from previous existences when, in fact, the government is the real cause. He became convinced by this teaching and abandoned Theravāda Buddhism and became a follower of Ashin Nyāna.

In the following, I will provide some tentative analyses of the interlinked deconversion and conversion narratives of my informants. To some extent, I will highlight the dynamics that may take place in the interplay between deconversion and conversion in their narratives. My informants recounted their deconversion from their position in the present, in which they had converted to Ashin Nyāna's teaching. Such narratives may have been informed by a "biographical reconstruction" (Snow and Machalek 1983:266-269), that is, "the past is reconstructed in light of the new meanings which emerge from one's present status as a convert" (Staples and Mauss 1987:135). The preconversion past tend to be depicted in negative light, as erratic and obscured by false views, and the

6 These were the passive Buddhists mentioned above. 
present as an improvement and a discovery of the truth. This reconstruction may involve exaggerations and even fabrications (Snow and Machalek 1983: 267-268). Such narratives thus tend to serve as tacit justifications and support of the present. Hereby, the passive and active modes mentioned above constitute local, cultural "genres for self-construction" - the self as a cultural, discursive product (Bruner 1997: 147). Thereby, this dichotomy served as a lens through which some of my informants structured their narratives.

What changes in conversion is the "universe of discourse," and is understood as a "radical change" conceptualised as "the displacement of one universe of discourse by another and its attendant grammar or rules for putting things together," a kind of paradigm shift (Snow and Machalek 1983: 265-266). ${ }^{7}$ In this way, deconversion is biographical change moving out of a state of naïveté and taken-for-grantedness (Streib et al. 2009: 23). Traditional Burmese Theravāda Buddhism and Ashin Nyāna's teaching represent diametrically opposite forms of Buddhism - enchanted and secular forms, respectively. The shift from one to the other thus represents an epistemic shift of a "universe of discourse." However, such shift seems to have been most evident among those who had practiced the (allegedly passive) devotional forms of Theravāda Buddhism (the second group), as the difference was greater between these two versions of Buddhism.

Religious doubt, Paloutzian explains, may emerge as a result of crises, for instance, of efficacy. In that case, "life circumstances happen that are inconsistent with deeply held beliefs, wants, expectations" (2005: 336; see also Higgins 1987: 322). That was an intrinsic part of the narratives in the second group. Since the majority of the Buddhists in Burma are socialised into traditional Theravāda Buddhism, it is part of their ingrained habitus. If their misery is explained by representatives from such an "allegiant" religious organisation to which society attributes a high degree of legitimacy and moral authority, they tend to blame themselves, rather than the religion in question, if discrepancies occur between their efforts, expectations and results (see Bromley 1998: 147-148). However, as we saw in the narratives of the women, this discrepancy that was explained with reference to bad karma from previous existences by the monks brought about frustration and emotional suffering, which prepared the ground for the emergence of doubt and later deconversion and its attendant "spiritual transformation" (see Paloutzian 2005: 337).

7 It could be added that this cognitive approach should be supplemented by a consideration of the impact of emotions and the body. Many of my informants emphasised a shift in their behavior and emotional orientation. 
In this way, these two women tended to depict their lives prior to conversion in a negative manner, as being filled by suffering, and to stress how their lives had improved after they had found the truth. They thus fit the pattern of shifting from the passive mode to an active one characterised by agency and empowerment seeking to embody the true teaching of the Buddha in their lives, even in their business activities. Their past was thus contrasted with the present in which they claimed to have found peace and become successful in business through Ashin Nyāna's teachings, thereby attributing success exclusively to themselves. ${ }^{8}$ These cases could be interpreted as "biographical reconstruction," in which "previously important events may be de-emphasised and less significant ones elevated to greater prominence" (Staples and Mauss 1987: 135). In other words, there may have been a tendency of over-emphasising preconversion hardships. As for the first woman, her shop, where I interviewed her, did not seem to be as flourishing as she tended to depict it. In this manner, a "crisis of purpose" can be followed by a "sense of purpose" after conversion (Paloutzian: 2005: 342). That perceived improvement is an important rhetoric strategy in conversion narratives. In these cases, loss of religious experiences (especially the second woman), implied moral criticism of the Buddhist monks and emotional suffering caused by their instructions, followed by doubt, as well as purely pragmatic, instrumental reasons, especially economic ones, were thus motives for leaving Theravāda Buddhism.

The epistemic shift was less radical for the secular people (the first group) who found an interpretation of Buddhism that harmonised with their worldview. Their deconversion process went faster, probably due to the fact that meaning systems change slowly (Paloutzian 2005: 339). The cognitive discrepancy between their secular worldview and Theravāda Buddhism caused some strain and intellectual doubt. They seemed to already have been looking for an alternative that would enable them to overcome that "cognitive dissonance" or "belief incompatibility" that may bring about tensions (see Higgins 1987: $3^{20-321)}$. For instance, the former communist's down-to-earth view on desire was incompatible with the ascetic one prescribed by Theravāda Buddhism.

Less discrepancy also characterised the spiritual seekers (the third group). They had already worked on various epistemes, such as insight meditation that, in contrast to ritualistic Theravāda Buddhism, is (like Ashin Nyāna's teaching) characterised by a high degree of rationality and emphasis on doctrines (see

8 This is a modern, individualistic, secular concept of agency and of an autonomous subject/ self that contrasts with agency within Burmese Theravāda Buddhism (dependence on monks and spirits). 
Houtman 1990). ${ }^{9}$ As Paloutzian (2005: 336-337) explains, doubt "set the process of questing in motion," and coping with such doubt likewise set the stage for "spiritual transformation." The two men were already in doubt regarding some teachings in Theravāda Buddhism and had set out to find the truth by critically examining various teachings. As one old follower said, those who become interested in Ashin Nyāna's teaching have not received satisfying answers from Theravāda Buddhist monks. Those belonging to the first and third groups were thus mainly motivated by intellectual doubt for leaving Theravāda Buddhism. In contrast to the second group, their lives do not seem to have changed dramatically after conversion and were therefore less inclined to depict their preconversion past in a negative manner. The second man in the third group experienced some frustration regarding meditation, but it did not seem to develop into a crisis, although a loss of religious experience was another motive for him to convert. Furthermore, he sought to distance himself from those characterised by the passive mode, thereby drawing on the local model for self-construction.

All informants in this sample, moreover, were motivated by moral criticism to convert, at least from their present point of view. Directly or indirectly, they claimed to previously have been exposed to false teachings and been deceived by the Theravāda monks and others. They were now convinced that they had found the truth and had achieved peace of mind. This is a common rhetorical figure in biographical reconstruction and may serve to vindicate their decision to leave and shift loyalties. Some adherents even resembled born-again Protestants and were very eager to spread the "true" teaching of the Buddha. This intense fervour could also be explained by the radical discrepancy between Ashin Nyāna's teachings and Burmese Theravāda Buddhism. It is less a difference in degree than in kind. The former communist even sought to persuade others from giving alms to the monks. Some viewed the monks as an unproductive burden for society and even as "rubbish," and one man had even felt "enslaved" by Theravāda Buddhism.

Although some followers have ceased giving alms to the Theravāda monks, others still do so for social reasons, presumably because they want to avoid being treated as social outcasts or disloyal apostates (compare Larsson 2018). That behaviour is similar to many Muslims living in Mandalay area who, for similar reasons, also give alms to the monks. To some degree, these two tendencies correspond to the exit roles in deconversion that Streib et al. (2009: $26-28$ ) refer to as "oppositional exit" and "integrating exit"; therewith it is here

9 However, insight meditation still operates within Theravāda's "universe of discourse." 
also implied a retaining of an oppositional and accommodating attitude, respectively, after conversion.

\section{$4 \quad$ Conclusion}

In this chapter, I have investigated cases of interlinked deconversion and conversion among Buddhists in Burma who had left the state-supported Theravāda Buddhism for a version of Buddhism that almost represents its inversion. The reasons my informants, divided into three groups, articulated for leaving included loss of religious experiences, doubt; moral criticism; and emotional suffering, as outlined by Streib et al. (2009), as well as more pragmatic, economic reasons. They had become followers of a monk whose teaching they regarded as the "true" teaching of the Buddha but that was declared illegal and "heretical" by the state. The degree to which there was a radical change of the adherents' "universe of discourse," as well as the applicability of the concept of "biographical reconstruction," varied between the three groups, and the highest degree could be observed among those who had practiced devotional Theravāda Buddhism. All three groups could retain a Buddhist identity, now reconstituted on the basis of a systematic alternative universe of Buddhist discourse, one that was better adapted to their lives mainly in urban modernising areas characterised by a growth of capitalism since the $1990 s$.

\section{References}

Braun, E. 2013. The Birth of Insight: Meditation, Modern Buddhism, and the Burmese Monk Ledi Sayadaw. Chicago: University of Chicago Press.

Bromley, D. 1998. "Linking Social Structure and the Exit Process in Religious Organizations: Defectors, Whistle-Blowers, and Apostates." Journal for the Scientific Study of Religion. 37:1, 145-16o.

Bruner, J. 1997. "A Narrative Model of Self-Construction." Annals of the New York Academy of Sciences. 818:1, 145-161.

Charney, M.W. 2006. Powerful Learning: Buddhist Literati and the Throne in Burma's Last Dynasty, 1752-1885. Ann Arbor: The Center for South and Southeast Asian Studies.

Foxeus, N. 2016. "Contemporary Burmese Buddhist Traditions." In M. Jerryson ed., Oxford Handbook of Contemporary Buddhism. New York: Oxford University Press, $1-33$. 
Higgins, E.T. 1987. "Self-Discrepancy: A Theory Relating Self and Affect." Psychological Review. 24:3, 319-340.

Houtman, G. 1990. “Traditions of Buddhist Practice in Burma.” PhD. London University, United Kingdom.

Ikeya, C. 2012. Refiguring Women, Colonialism, and Modernity in Burma. Chiang Mai: Silkworm Books.

Janaka Ashin, and Crosby. K. 2017. "Heresy and Monastic Malpractice in the Buddhist Court Cases (Vinicchaya) of Modern Burma (Myanmar)." Contemporary Buddhism. 18:1, 199-261.

Larsson, G. 2018. "Disputed, Sensitive and Indispensable Topics: The Study of Islam and Apostasy." Method and Theory in the Study of Religion, 1-26.

Paloutzian, R F. 2005. "Religious Conversion and Spiritual Transformation: A MeaningSystem Analysis." In R.F. Paloutzian and C.L. Park eds, Handbook of the Psychology of Religion and Spirituality. New York: The Guilford Press, 331-347.

Rambo. L.R. and Farhadian, C.E. 2014. "Introduction." In L.R. Rambo and C.E. Farhadian eds, Oxford Handbook of Religious Conversion. New York: Oxford University Press, $1-28$.

Snow, D.A. and Machalek, R. 1983. "The Convert as a Social Type." Sociological Theory. 1, 259-289.

Spiro, M.E. 1982 [1970]. Buddhism and Society: A Great Tradition and its Burmese Vicissitudes. 2nd edition. Berkeley: University of California Press.

Staples, C.L. and Mauss, A.L. 1987. "Conversion or Commitment? A Reassessment of the Snow and Machalek Approach to the Study of Conversion." Journal for the Scientific Study of Religion. 26:2, 133-147.

Streib, H., Hood, R.W. Jr., Keller, B., Csöff, R-M., and Silver, C.F. 20o9. Deconversion: Qualitative and Quantitative Results from Cross-Cultural Research in Germany and the United States of America. Göttingen: Vandenhoeck and Ruprecht.

Tin Maung Maung Than. 1993. "Sangha Reforms and Renewal of Sasana in Myanmar: Historical Trends and Contemporary Practice." In T. Ling, ed, Buddhist Trends in Southeast Asia. Singapore: ISEAS, 7-63.

Tint Lwin. 1997. "Contextualization of the Gospel: An Effective Strategy for Evangelization of the Theravada Buddhists in Myanmar," PhD, Faculty of the Southern Baptist Theological Seminary, Louisville. 